\title{
A Cataguases de Luiz Ruffato em O mundo inimigo (2005)
}

\author{
The Cataguases of Luiz Ruffato in O mundo inimigo (2005)
}

\author{
CAMILA Galvão DE SOUSA ${ }^{1}$ \\ JOELMA SANTANA SIQUEIRA' \\ 1 Universidade Federal de Viçosa (UFV). Viçosa, MG, Brasil.
}

\begin{abstract}
av
Resumo: Este artigo analisa a representação da cidade nas narrativas-capítulos do romance contemporâneo $O$ mundo inimigo de Luiz Ruffato, publicado em 2005 pela Editora Record. A cidade mineira Cataguases, em Minas Gerais, que na transição do século XIX para o XX, passou pelos processos de urbanização, industrialização e modernização, é o espaço central do romance e cidade natal do escritor. No entanto, Luiz Ruffato, através de uma narrativa moderna, permite que suas personagens, pertencentes à classe trabalhadora, falem por si para apresentar uma perspectiva diferente das questões destacadas em livros sobre a história da cidade, já que são impedidas de conviver na dinâmica urbana.
\end{abstract}

Palavras-chave: literatura e cidade; o trabalho na literatura; romance brasileiro contemporâneo.

\begin{abstract}
This article analyzes the representation of the city in the narratives-chapters of the contemporary novel Luiz Ruffato's $O$ mundo inimigo, published in 2005 by Editora Record. The mining town of Cataguases in Minas Gerais, which in the transition from the nineteenth to the twentieth century, went through the processes of urbanization, industrialization and modernization, is the central space of the novel and hometown of the writer. However, Luiz Ruffato, through a modern narrative, allows his characters, belonging to the working class, to speak for themselves to present a different perspective of the issues highlighted in books on the history of the city, since they are prevented from coexisting in urban dynamics.
\end{abstract}

Keywords: literature and city; work in literature; contemporary Brazilian romance.

Regina Dalcastagnè (2012, p. 110), em Literatura brasileira contemporânea: um território contestado, destaca a cidade como "um símbolo da sociabilidade humana, lugar de encontro e de vida comum". Luis Alberto Brandão Santos (1999, p. 131), por sua vez, em "Textos da cidade", destaca-a como a organização social que "melhor representa a maneira como o homem da atualidade se relaciona com o espaço e se organiza no tempo". A partir de sua transformação, com a substituição da economia agrária pela industrial, houve, na literatura brasileira, um maior interesse pelo cenário urbano, por ter influenciado. O espaço urbano, como afirma Célia Helena Castro Gonsales, no artigo "Cidade moderna sobre cidade tradicional: conflitos e potencialidades", "é o espaço coletivo e das relações humanas por excelência, o espaço da vida da cidade, a mudança do caráter formal desse 'lugar' necessariamente influenciará nos comportamentos ali ocorridos". Aspectos políticos, econômicos, sociais e culturais passaram a ser representados no tecido textual, relativizando, inclusive, o conceito de progresso.

Essa questão foi mais problematizada, no Brasil, pelos romancistas do modernismo da década de 1930, que, ao observar um processo de urbanização e modernização extremamente excludente, possibilitaram a discussão sobre a inadaptação do sujeito em sociedade, compondo o que Fernando Gil (1999, p. 15) denomina de "romance da urbanização"2 e, enfatizando, assim, a presença

\footnotetext{
1 GONSALES, Célia Helena Castro. "Cidade moderna sobre cidade tradicional: conflitos e potencialidades" (partes 1 e 2). Arquitextos, ano 05, abr. 2005. Disponível em: $<$ https://goo.gl/mtm8Wu>. Acesso em: 25 out. 2015.

2 O conceito "romance da urbanização", de Fernando Gil, problematiza a construção formal de três narrativas específicas que revelam os impasses e as contradições da transição do Brasil rural para o urbano e industrial: Os ratos (1935), de Dyonélio Machado, Angústia (1936), de Graciliano Ramos e O amanuense Belmiro (1937), de Cyro dos Anjos.
} 
de dualidades próprias desse período transitório (mas inconcluso) permeado de contradições e ambiguidades: moderno e arcaico, novo e antigo, civilização e barbárie. Aspectos que foram amplificados na cidade contemporânea globalizada e em constante crise, que ainda segrega, expele, devora e rejeita certos grupos sociais, como destaca Renato Cordeiro Gomes (2008).

O estudo da representação da cidade na literatura, em voga, principalmente, na contemporaneidade pelos estudos culturais, é apresentada por Gomes (2008, p. 23), em Todas as cidades, a cidade: literatura e experiência urbana, publicado em 1994, e ressalta que o símbolo da cidade, através do discurso ficcional, é "capaz de exprimir a tensão entre racionalidade geométrica e emaranhado de existências humanas". Além disso, Gomes (1999, p. 23), em seu artigo "A cidade, a literatura e os estudos culturais: do tema ao problema", destaca que "a desmedida do espaço afeta as relações com o humano". A cidade é analisada como um tecido, ou um texto, construído por um discurso sensível, como necessidade histórica, a partir de fragmentos, colagens e perspectivas parcelares, provisórias, das experiências urbanas de quem as lê e descreve, cuja leitura é travessia e estabelecimento de conexões, visto a impossibilidade de totalização e de representá-la como um todo, abarcando, dessa forma, autor, obra e público leitor. E, o autor (2008, p.53) reitera: "narrar (a cidade) é transformar (transformá-la)", pois a cidade representada na literatura ultrapassa muitas vezes sua função de cenário, para se tornar personagem da narrativa, capaz de expressar, além das características físico-geográficas, a cultura, os costumes, os tipos humanos e a cartografia simbólica, "em que se cruzam o imaginário, a história, a memória da cidade e a cidade da memória" (2008, p. 24).

Fernando Gil (1999, p.29), tratando sobre o temaproblema que envolve o cenário urbano, propõe que as narrativas da contemporaneidade "constroem e ativam as imagens da cidade, que são cultural e historicamente determinadas". Nesse sentido, como observa Renato Cordeiro Gomes (2008, p. 147), outras formas literárias são pensadas para atender ao caráter "passageiro, fluido, contingente, dinâmico" da cidade:

Considerando que a cidade é o lugar em que o fato e a imaginação teriam de se fundir, aceitando, por outro lado, o fragmentário, o descontínuo, e contemplando as diferenças, os discursos contemporâneos cenarizam e grafam a cidade, com sua polifonia, sua mistura de estilos, sua multiplicidade de signos, na busca de decifrar o urbano que se situa no limite extremo e poroso entre realidade e ficção (GOMES, 1999, p. 29).

Para Gomes (1999, p.26), a cidade constitui, nos tempos atuais, uma questão fundamental, pois "tornou-se uma paisagem inevitável, pólo de atração e de repúdio, paradoxalmente uma utopia e um inferno". Corroborando com as considerações de Gomes, Dalcastagnè (2012, p. 111) enfatiza o espaço predominantemente urbano na narrativa brasileira contemporânea como uma partícula fundamental para "a definição das personagens e de suas relações com o tempo circundante", apesar de que há, nessas narrativas, o mínimo de descrições de ambientes, pelo reconhecimento instantâneo promovido pela indústria cultural, como também pelo fato de que as cidades muito se parecem, até mesmo em seus problemas ocasionados pela "urbanização, desterritorialização, transformações nas esferas públicas e privadas, segregação". Portanto, ela mescla as metáforas da polis grega e da Babel moderna para contemplar, ao mesmo tempo, diversidade e desarmonia, com base na constatação de Luis Alberto Brandão Santos (1999, p. 135), em "Texto da cidade", ao caracterizar a cidade grande como "o espaço da confusão, do desentendimento irredutível e da impossibilidade de os homens se comunicarem - a inviabilidade mesma de um projeto comum". A esse aspecto vem juntar-se a observação de Dalcastagnè $(2012$, p.14) de que na literatura a cidade ainda é "domínio de poucos, afinal, barreiras simbólicas determinam o lugar de cada um". A rua é ainda destinada aos homens e o espaço privado às mulheres, enclausuradas e confinadas na esfera doméstica, o que reitera a desigualdade social e a naturalização do discurso dominante presentes nos dias atuais.

Conforme observa Dalcastagnè (2012, p. 14), "algumas áreas também são vedadas aos pobres e malvestidos, exceto quando se encontram na posição de serviçais, ao passo que outras, mais degradadas, são seu domínio". Portanto, quando as personagens pertencentes aos estratos sociais marginalizados ocupam certos espaços é necessário que se conformem "com os restos - as favelas, a periferia, os bairros decadentes, os prédios em ruínas. Mesmo o trânsito em determinados lugares e ruas lhes é vetado, como se houvesse placas, visíveis apenas para elas, dizendo "não entre" (2012, p. 120). E é assim que, paradoxalmente, a cidade lhes parece cada vez mais distante...

A primeira edição de $O$ mundo inimigo foi publicada em 2005 pela editora Record e corresponde ao segundo volume do projeto literário Inferno Provisório de Luiz Ruffato. O romance é constituído por doze narrativascapítulos, cujos títulos são respectivamente, "Amigos", "A demolição", "O barco", "A solução", "A mancha", "Jorge Pelado", "Ciranda", "Paisagem sem história", "A danação", "A decisão", "Um outro mundo" e "Vertigem". A denominação narrativas-capítulos se refere ao fato de poderem ser lidas isoladamente sem perderem vínculos em relação, principalmente, ao espaço e à trajetória das personagens, constituindo, portanto, um romance- 
mosaico, que demanda diversas leituras atentas para que as conexões entre essas narrativas sejam percebidas.

Em $O$ mundo inimigo a presença de um narrador em terceira pessoa é recorrente. No entanto, não é possível afirmar que seja apenas um no conjunto das narrativas do romance pois, além de não explicitar a relação entre os doze capítulos, o narrador (ou os narradores) se comporta(m) de diferentes maneiras para acompanhar as trajetórias das personagens, permitindo que eles falem por si sem a interferência desse(s) narrador(es), e, inclusive, alterando as estruturas frasais e da narrativa. Ou seja, a narração não ocorre fixa em apenas uma personagem e, portanto, não há nenhuma protagonista, pois cada narrativa-capítulo focaliza um núcleo de personagens. Também não há uma organização temporal linear no romance, nem uma delimitação de início e fim, embora a decadência do Beco ocorra na última narrativa. Em diversos momentos, há espaços em branco, reticências, alterações de tipo de fontes e marcações em itálico e negrito que demarcam, principalmente, fluxos de consciência, reminiscências, reflexões, sonhos, diálogos e vozes das personagens, ou ainda um domínio precário da linguagem por parte de determinada personagem. Muitas vezes, não é possível identificar claramente, apenas supor, a voz que narra.

As narrativas-capítulos de $O$ mundo inimigo se associam, fundamentalmente, por dois pontos: o estrato social das personagens, que pertencem à classe trabalhadora, e o espaço central, que é o Beco do Zé Pinto, situado no bairro Vila Teresa em Cataguases. Essas duas questões estão relacionadas pois, a partir do empreendimento de Zé Pinto, que oferece, além de moradia, condições materiais em diferentes níveis para subsistência de seus inquilinos trabalhadores, é que ocorre a interação entre as personagens que são apresentadas por diferentes perspectivas no decorrer do romance. Através do Beco, também é possível observar, a partir das impressões das personagens, a transformação do espaço urbano para atender às necessidades de uma sociedade de trabalhadores em formação ou às demandas políticas e sociais ocasionadas pelos processos de urbanização e industrialização.

A cidade de Cataguases, situada na zona da mata mineira, às margens do rio Pomba e do ribeirão MeiaPataca, obtém destaque, ainda nos dias de hoje, pela repercussão, nacional e internacional, nas primeiras décadas do século XX, de suas manifestações modernistas nas artes em geral, com destaque para a consolidação da Revista Verde, de 1927. Essas manifestações alteraram a fisionomia urbana do município com a implantação de obras de pintura, escultura, arquitetura e paisagismo nas praças, prédios, monumentos públicos e residências particulares de diversos artistas como Oscar Niemeyer, Francisco Bologna, Burle Marx, Anísio Medeiros,
Ceschiatti, Marcier etc. Dezesseis delas, localizadas no centro da cidade, foram tombadas pelo Instituto do Patrimônio Histórico e Artístico Nacional (IPHAN) em 1994.

Outro fato que se destaca na história de Cataguases, quando se fala na transição do século XIX para o XX, além dessa veia cultural da cidade, é o estabelecimento das indústrias, no processo de urbanização, modernização e industrialização. Tais questões fizeram com que em obras, como O Município de Cataguases (1908), de Arthur Vieira de Rezende e Silva, Pequena história sentimental de Cataguases (1969), de Enrique de Resende, e Cataguases centenária (1977), de Levy Simões da Costa, a cidade fosse adjetivada como "progressista", "dinâmica" e "realizadora", enfatizando, dessa forma, as mudanças que, pelo menos na teoria, atingiram os níveis cultural, econômico, político e social.

Isso posto, destaca-se o fato de que na narrativa de Luiz Ruffato a vivência das personagens em $O$ mundo inimigo, em sua maioria trabalhadores das indústrias têxteis da cidade, revela uma história que não condiz com a apresentada oficialmente, em que civilidade, cultura e progresso são evidenciados. Trata-se de uma perspectiva diferente daquela dita oficial ou uma "História a contrapelo", para utilizar o conceito de Walter Benjamin (1994).

Como o romance fragmentado, os recortes de jornal que estampam a parede da personagem Cidinha e a distribuição das casas do Beco... a vida de cada uma das personagens de $O$ mundo inimigo pode ser lida como peças de um mosaico, já que nenhuma história é definitivamente delineada. São operários, lavadeiras, domésticas, alcoólatras, prostitutas, desempregados... que compartilham de uma miséria (que vai além da financeira) e de uma violência (que vai muito além da física) em um espaço urbanizado e excludente. Apesar de transitarem pela cidade, parecem que a ela não pertencem, representando, assim, o autoritarismo político que eternizou a morfologia urbana brasileira. Mesmo não satisfeitos com as condições de vida, as personagens tendem a se conformar com a realidade do Beco. No entanto, algumas partem.

A primeira cena do romance já oferece indícios de seu espaço urbanizado, com os operários, na noite de Natal, saindo apressados da Manufatora. Acompanhando a perspectiva de Luzimar, que, de bicicleta pelos paralelepípedos das ruas, retorna para casa, em "Amigos", o narrador percorre a Vila Domingos Lopes, Rua do Comércio... até chegar à Vila Teresa. Ao atravessar a Ponte Nova, observa o rio "gordo", reflexo do excesso de chuvas de dezembro que pode ocasionar enchentes nessa região. Essas referências à cidade, e outras tantas que surgem ainda na primeira narrativa, são facilmente 
relacionadas a Cataguases, pela semelhança de descrições de ruas e bairros. No entanto, seu nome ainda não é revelado explicitamente.

O que é possível identificar, primeiramente, é a presença marcante da indústria, pois Luzimar trabalha no setor de embalagens da Manufatora, ainda que outros moradores busquem melhores empregos e condições materiais em grandes centros, como fizeram Gildo, Gilmar e Zito Pereira indo para São Paulo. A simplicidade da casa de Dona Marta é apresentada em detalhes a partir da perspectiva incômoda de seu filho Gildo, que não pertence mais àquele espaço, como revelam os adjetivos destacados por vírgulas no início dos períodos da passagem a seguir ("corpulento", "sôfrego", "impaciente"):

Corpulento, Gildo - bermuda jeans, camiseta-de-propaganda puída, chinelo havaiana - arrasta Luzimar. Sôfrego, escancara as janelas e arranca as capas de tecido ordinário que sobre protegem da poeira o sofá e a poltrona, amarrotando-as sobre a caixa ainda fechada da televisão. Impaciente, limpa a mesinha-de-centro de pedra-de-mármore do cinzeiro em forma de coração e da margarida-de-plástico enterrada no solitário (...) (RUFFATO, 2005, p. 16) . $^{3}$

A partir dos filhos de Dona Marta, Gildo e Gilmar, é possível observar o trânsito das personagens entre as cidades de Cataguases e São Paulo, pois ambos mudaram sob a influência do Tio Gesualdo e em busca de melhores condições materiais. Gildo, operário na capital paulista há alguns anos, ao encontrar com o ex-amigo de infância Luzimar, em "Amigos", enumera, com orgulho, os ganhos conquistados: o fusquinha recém adquirido e a TV que trouxera para presentear a mãe. Para ele, São Paulo "É grande... E boa pra ganhar dinheiro", enquanto Cataguases "é uma bosta, não tem nada..." (p.21) e, além disso, durante as visitas a sua cidade natal, sente-se em um "outro mundo" (p. 24), não reconhece mais Cataguases, os amigos, os familiares e, ao que parece, nem a si mesmo. A estrutura dessa narrativa é fragmentada e prevalece o discurso direto.

Os comportamentos de Gildo também deixam transparecer os frios sentimentos em relação à família e aos amigos: ao relatar o destino de seus irmãos, no tratamento grosseiro com sua mãe e, principalmente, na atitude de menosprezo e exibicionismo com Luzimar ao comparar as oportunidades oferecidas pelas duas cidades, bem como o destino deles:

- Eu tenho pena de você, cara. Pena mesmo, juro... Porque você está fodido... Já estou até vendo: daqui a pouco vêm os filhos, uma fieiras deles, e você aí,

\footnotetext{
3 Todas as citações de $O$ mundo inimigo foram extraídas da edição de 2005 publicada pela editora Record.
}

dando duro na fábrica... O salário não chega, eles param de estudar, vão pegar no batente pra ajudar... E você ficando velho... Um dia, quando menos perceber, acabou... é o fim da linha... E que merda de vida você levou, cara!, que merda de vida! (p.24-25).

"A demolição" é uma narrativa-capítulo dividida em quatro partes: "1. Julho incendiado", que se refere ao dia da mudança de Gilmar para a capital paulista, em que Cataguases é comparada ao Inferno, bem como de sua trajetória, "2. Disney", que revela o sonho de suas duas filhas que pode ser realizado a partir da venda da casa, como também os motivos que levaram Dona Marta a tomar tal decisão, "3. O espaço no tempo", que apresenta a efetivação da venda da casa; por fim, "4. O porão", cujas rememorações do passado fazem com que Gilmar mude de perspectiva.

O nome da cidade aparece efetivamente quando Dona Marta resolve vender sua casa, localizada no bairro Vila Teresa, onde morava há quarenta e cinco anos. Decide "dividir o dinheiro, mudar para Santo Antônio de Pádua e estar com as irmãs, a Leda, solteira, a Vera, viúva, tudo acordado entre elas, não aguentava mais a solidão, os filhos distantes" (p.33), o que proporciona rememorações de um passado que não volta mais. Nesse instante, o desenvolvimento da cidade é enfatizado, pois Dona Marta demonstra um embate entre o passado rural e o presente urbano, seguido de inadaptação em meio ao progresso: "a cidade engordou, já não pode deixar a porta encostada, uma ladroeira!" (p.34).

Essa narrativa, fixada nos pensamentos do filho Gilmar, revela um lado mais sentimental de seu irmão Gildo, pelas idas constantes a Cataguases e cujas desculpas eram sempre: "Aniversário da velha, coitada, a gente nunca sabe se vai ter outro, Dia das Mães, cara, Dia das Mães é foda!, Não podia deixar ela passar sozinha as festas de fim de ano" (p.29-30). Enquanto ele, que jurava nunca mais voltar à cidade, repensou tal decisão, tomada ainda na adolescência, ao saber da possível demolição da casa dos pais onde passara a infância. Esse fato reforça a importância afetiva da casa, ou melhor, do lar, do lugar onde passou a infância, capaz de proporcionar um mergulho interior e um resgate aos mistérios do passado, ilustrados pelo episódio do sumiço de Tiquinho, cujo desfecho é uma incógnita para o leitor da narrativa, assim como para os envolvidos no episódio.

Em São Paulo, o desejo de Gilmar era seguir carreira futebolística em um grande time, ganhar muito dinheiro e ficar famoso. No entanto, um pequeno acidente em campo tornou-o "imprestável para o trabalho" (p.32), encerrando, dessa forma, a sonhada carreira aos 28 anos: "sem os meniscos, o joelho sempre inchado, inflamado" (p.32). Entre as idas e vindas por hospitais, conheceu 
uma enfermeira do setor de Raio X. Casou-se. Seu sogro, "aposentado da Light, conseguiu empréstimo na Caixa Econômica" (p.32-33), reformou a garagem do sobrado para montar um botequim que virou, com o devido empenho, gradativamente, bar-e-restaurante, cujas lembranças da curta carreira eram exibidas com muito orgulho. Estava "bem de vida em São Paulo" (p.29) e desejava, com o dinheiro da venda da casa, realizar o sonho de suas duas filhas: conhecer a Disney. Uma extravagância, admitia Gilmar.

O circuito entre Cataguases e São Paulo também reaparece em "A Danação", cuja estrutura narrativa mescla passado e presente, com demarcações em itálico e negrito. A personagem Zito Pereira concretiza o desejo de retornar a Cataguases e, no Beco, constitui família. A trajetória de Zito é marcada pela transição da economia agrária pela industrial, conforme passagem a seguir:

Na Serra da Onça ajudava o pai na mantença da fieira de filhos, um a cada ano, metade anjinhos enterrados no quintal, metade doentinhos que teimavam em falar, comer... Quando completou dez, onze anos, a roça de milho e fumo, que tocavam à-meia, desandou, empurrando-o para longe das asas da mãe. Arranjou-se em Cataguases, nos fundos de uma oficina mecânica, entrou no Senai, Deus sabe como, e de lá atirou-se à vala comum, São Paulo" (p. 136).

Caracterizando São Paulo como uma "vala comum", por ser constantemente o destino de quem busca melhores condições de vida, ele enumera os fracassos na capital, que contrariavam as expectativas de outrora. Frustrado, Zito decide retornar a Cataguases, apesar dos aconselhamentos de um colega que já havia passado pela experiência falhada do retorno, sob a justificativa de que em sua cidade natal seria diferente devido às oportunidades de emprego:

Após três anos em São Paulo, resolveu voltar. Falou no emprego que não aguentava mais, que toda noite sonhava com Cataguases, que nunca mais tivera notícia da família, que se sentia um mequetrefe naquela cidade tão enorme. Um baiano, que trabalhava com ele, falou, Mineiro, eu estava bem aqui, me deu um troço, comprei passagem pra Serrinha, larguei tudo. Dei com os burros n'água. Tive que voltar com o rabo entre as pernas. O Brasil tem jeito não. Só aqui a gente véve decente, sabendo que pode contar com ordenado certo no fim do mês. É, mas lá na minha cidade tem muita indústria, se o sujeito tiver cabeça dá pra viver no de-acordo (p. 140, grifos do autor).

Nessa passagem, a dominação do dinheiro na mentalidade do metropolitano, observada por Simmel, fica evidente, assim como a dificuldade de adaptação a tal realidade, que exige relações exclusivamente trabalhistas e impessoais, e, consequentemente, a perda de laços afetivos e familiares. Zito identifica Cataguases como a "minha cidade" e retorna. Mesmo com a presença de muitas indústrias foi extremamente difícil conseguir uma colocação e, portanto, a frustração permanece. Após inúmeras tentativas, consegue uma colocação como ajustador-mecânico na oficina da Manufatora. Depois de quinze anos de Fábrica, Zito é despedido, mesmo com tantos filhos para sustentar e certificações técnicas, com a justificativa de uma crise no mercado de algodão. "Morava num porão úmido, cômodos separados por compensados. Esse, o resultado de anos e anos de labuta" (p. 141), lamentava desempregado, pensando no exemplo que daria aos filhos. Ou seja, Zito Pereira não encontrou o que foi buscar em Cataguases.

$\mathrm{Na}$ narrativa-capítulo "O barco", há a presença de uma ambientação contrastante dentro da cidade de Cataguases: de um lado, a predominância da perspectiva de Marlindo, pai de Luzimar e Hélia, pajem de Osvaldo e morador do Beco; do outro, alguns flashes que destacam a perspectiva de Dona Geralda, mãe de Osvaldo, viúva de um médico e vereador importante, moradora da Rua do Pomba, que representa o único núcleo de personagens pertencentes à classe média, cuja casa é observada em detalhes, apenas do lado de fora, pela perspectiva de quem é do Beco:

Um muro alto, enfeitado de cocares de cacos-devidro, isola o terreno da rua. A ligação, um portão fechado de ferro inteiriço, carcomido nos baixios. Um caminhozinho de pés-de-moleque que une o lá-fora aos cinco degraus da varanda, ensombreado por um teto de idosas parreiras estéreis e ladeado por um avoego jardim: ervas-daninhas sufocando beijos-estudantes, brincos-de-princesa, rosas-japão, moças-velhas, onzehoras, bocas-de-leão, damas-da-noite, margaridas (...) (p. 41-42).

Observa-se no espaço da casa um terreno externo amplo, mas decadente e abandonado. Através de Romualdo, marido de Dona Geralda, é possível observar o poder de influência dos empresários numa cidade industrial, representado, no romance, pela família denominada "Prata", que, apesar de não assumir nenhum papel efetivo, representando apenas "nomes de ruas, donos das fábricas" (p.103), influenciava no cotidiano dos moradores do Beco e reforça a desigualdade social da cidade.

Romualdo, clínico importante formado em Medicina pela Universidade do Brasil, no Rio de Janeiro, mesmo com uma conduta suspeita, garantia reeleições com atendimentos médicos gratuitos oferecidos à população, 
mas também com ameaças de desemprego aos operários, articuladas com o auxílio dos "Pratas". Nesse monopólio político, portanto, não havia outras opções de emprego na cidade, nem sequer a possibilidade de exigir melhores condições de trabalho e salário, nem mesmo a formação de sindicatos (que em nenhum momento aparecem no romance).

Nas duas transcrições a seguir, é possível observar a fama de Romualdo, bem como a fraude das eleições, cujos votos eleitorais, único "direito" de voz dos cidadãos, eram manipulados pelos industriais. Ou seja, mesmo com a mudança da economia local, a mentalidade do favoritismo e do "voto de cabresto" permanecia.

Ficou falado na cidade inteira, o que não o impediu de entrar na política e tornar vereador bem votado. Fiava-se no afamado entra-e-sai de gente em busca de uma consulta grátis, de uma remessa de tijolo, pedra ou areia, do pagamento de uma conta pendurada, de uma palavra amiga (p.53).

Eleição, ganhava uma agarrada a outra, verdade que ajeitadas pelas mãos dos Prata. Em-antes de adentrar a seção para votar, o eleitor soletrava o nome para o cabo-eleitoral conferir na lista dos empregados das fábricas. Se as urnas parissem menos votos que os garantidos, ia a fieira para o olho da rua. Sem dó, sem piedade (p. 55-56).

Walter Benjamin (1994, p. 225), no ensaio "Sobre o conceito de história", em Magia e técnica, arte e política, através da imagem de uma tempestade, representa essa ilusão que permeia os discursos do progresso e da civilidade cristalizados pelos que detêm o poder, como representado pela política de Cataguases na ficção, comandada pela família Prata, pois "a cultura não está isenta de barbárie”. Além disso, Benjamin conceitua a história como construção (assim como a literatura), cujas imagens do passado são fixadas através do materialismo histórico e passíveis de reflexão a partir de um determinado distanciamento.

Portanto, Ruffato apresenta a "história a contrapelo" através do discurso de suas personagens de $O$ mundo inimigo, já que assume uma perspectiva que não condiz com a apresentada oficialmente. Em consonância com essas questões, Marcos Vinícius Ferreira de Oliveira (2013, p. 15), em estudo sobre a pentalogia de Ruffato, constrói as metáforas da máscara e da ruína para representar "a passagem do estágio da economia agrária, liberal na teoria, escravista e concentradora na prática, para um cenário de industrialização e de urbanismo, concentrador na teoria e na prática, em razão das diretas interferências do poder político", que, como ainda aponta Oliveira, proporcionou uma vida intelectual para poucos. Ele explica:
(...) a "máscara" esconderia o rosto do projeto modernista que caiu, enquanto modelo emancipador, uma vez que seus mentores possuíam a intenção de fazer de Cataguases um grande laboratório experimental de sociedade avançada. A ruína do projeto, acreditamos, deu-se muito em função de sua própria incapacidade de proporcionar a tão propalada autonomia (OLIVEIRA, 2013, p. 35, grifos do autor).

Ainda em "O barco", Dona Geralda, já viúva, compara, primeiramente, as expectativas na época do casório com suas percepções atuais: "A felicidade... Ah, a ignorância do vindouro! Se soubesse...” (p.45). Lamenta que, apesar da rotina movimentada de sua casa antes da morte de Romualdo (por um fulminante ataque do coração), agora estava literalmente sozinha:

Geralda olhou à roda, as vozes esfumaram-se. Onde a romaria?, pobres, ricos, pretos, brancos, morenos, mulatos? Onde os amigos?, vizinhos?, aproveitadores? As entediadas águas do Rio Pomba silenciaram-se, convenientes. Meu Deus, tanto trabalho!, brancas noites, adiadas viagens, inconclusos passeios, bobas alegrias, infundadas preocupações, para quê?, para isso? (p. 46).

Relembra também o nascimento dos dois filhos (Osvaldo e Bernadete) e a falta de fidelidade do marido, bem como suas promessas, cujo arrependimento só ocorreu prestes a morrer. Enquanto Osvaldo sofria com o esgotamento, Bernadete aos poucos se tornava ainda mais ausente, após casamento e mudança: "De São Paulo, escrevia de quando em quando, o apartamento, as crias, as novidadezinhas. Uma carta de quinze em quinze dias, uma carta por mês, uma carta por ano, nenhuma carta. Um obrigatório telefonema no Natal, nos aniversários" (p.46). Dona Geralda reflete consigo mesma sobre seu testamento: "um marido adúltero, uma filha sem-alma, um filho bobo" (p.58). E, assim, aguarda o dia de sua morte. Dessa forma, com a história de Dona Geralda a precariedade não ocorre apenas no nível econômico, pois, apesar de dispor de possibilidades mais alargadas de conforto e segurança, a precariedade, a solidão e a desintegração permanecem.

Através desse núcleo de personagens, Ruffato representa diferentes olhares sobre um mesmo fato, o que reforça a questão de que cada um observa de acordo com o lugar que ocupa na sociedade, já que a perspectiva de Adelaide não vai de encontro com a de Dona Geralda. Adelaide foi criada, desde os oito anos, pelo pai do doutor Romualdo. E auxiliava toda a família em todos os aspectos relacionados aos afazeres domésticos, o que indica, dessa forma, resquícios ainda escravocratas: 
Acordava na primeira hora, ajudava na feitura do café-da-manhã, na tomação de conta dos meninos e meninas, na faina do almoço, no cosimento dos andrajos, no labor do jantar, na lavação dos pequenos, na arrumação dos estoques, e ia dormir no adiantado das horas. Todos os dias. Inclusive sábados, domingos e dias-santos-de-guarda (p. 48).

Portanto, não viu sua vida passar. Cresceu sem perceber a si mesma, sempre em função dos outros. Aos 30 anos, "sozinha, sem lar, sem dinheiro, sem família, sem nada" (p.48), recebeu uma medalhinha de Santa Rita como paga e foi dispensada. Muito tempo depois, Romualdo resgatou-a "hominizada de-favor nos fundos de uma casinha humilde na Vila Reis" (p.48). Mas ainda sim, Adelaide tem voz na narrativa e revela um ponto de vista diferente do de Dona Geralda, com quem ainda vive, pois sempre destaca as boas intenções de Romualdo, por quem revela muito apreço, talvez por ter acompanhado sua trajetória desde o nascimento. Adelaide afirma que o único erro de Romualdo foi sua escolha para esposa, pois, segundo ela, Dona Geralda era uma mulher que "nunca tinha colocado os pés numa cozinha, que nunca tinha lavado muda de roupa, que nunca tinha sujado as mãos num cocô de neném. Que parecia estar sempre de caganeira, com aquela cara-de-quem-comeu-e-não-gostou" (p.49). Além disso, afirma que a fama de que Romualdo mantinha casos extraconjugais era "tudo invencionice!" (p.50). E justifica a mudança de Bernadete, de quem tinha muitas saudades, por não ter aguentado tantas fofocas, e a doença de Osvaldo como frescura, manha, já que ele "puxou a mãe" (p.50). Sua visão é carregada do senso comum de uma sociedade patriarcal que vê o homem como o forte e poderoso e a mulher como figura obrigada a protegê-lo.

O pajem Marlindo reitera a fama de Romualdo, relembrando seu velório, cujo caixão foi disputado por várias mulheres e os filhos não compareceram. O pai de Hélia e Luzimar é focalizado, logo no início da narrativa, mastigando "a aba do chapéu de palha que giragirava" em suas "mãos turbeculosas", em pé, mantendo a distância hierárquica de "três degraus abaixo" (p.41) para conversar com mãe de Osvaldo. A partir de então, em um movimento em que o narrador onisciente se aproxima e emite o ponto de vista de Marlindo, aos quarenta e três anos, sendo que "o povo daria bastantes mais" (p.43), a personagem é caracterizada como envelhecida pelo excesso de trabalho, cujas marcas estão expressas em seu próprio corpo, conforme ilustra o fragmento a seguir que merece transcrição pela sutileza e precisão dos elementos que compõe a descrição:

Franzinho, magro, transparente. Uma larga estrada devastara seus cabelos, no antigamente, e uma berruga enorme encapelava seu cocoruto. Rosto escavado pela bexiga, olhos mel escondidos em covas enegrecidas. Desconhecia pai e mãe, indigentes enterrados em rasas sepulturas no cemitério de Guiricema. Dera duro para engrenar como gente. O pão que o diabo amassou, comera com gosto (p. 43).

O campo semântico ("devastara", "encavado", "escondidos", "covas" etc.) que permeia essa descrição, seguido de uma expressão popular complementada ("comera com gosto"), começa a oferecer indícios, pela perspectiva do narrador, da trajetória de Marlindo, narrada de forma não linear nas páginas subsequentes. Entre suas experiências de trabalho, desde uma roça de arroz à função de pajem, destacam-se:

\begin{abstract}
Num ano só, seis vezes mudaram. De cidade. Uma roça de arroz desandada, em Guiricema. Mão na frente, mão atrás, em Cataguases. Rachando lenha em Dona Eusébia. Chutando lata em Cataguases. Vendendo caramujo em Leopoldina. Cataguases, novamente. E Zulmira deu um basta. Um chega. Morreriam de fome em Cataguases. Pronto! Assumiu a rédea. Marlindo demandou serviço na Industrial. Carteira assinada. Varria o chão, avolumando o algodão pelos cantos. Deu para trás. Não nascera para empregado. Comprou um carrinho-de-pipoca. Arrumou licença na Prefeitura para trabalhar na Praça Rui Barbosa, em frente ao Cine Edgard. Sobrevivia. Mas, meu deus, e a paradeira? Fez-se sócio de uma venda na Vila Minalda. Nas prateleiras, macarrão, apenas. Do fino, do grosso, goela-de-pato, cabelo-de-anjo, estrelinha. Só mosquitos ultrapassavam a soleira. De volta à labuta. Agora, graças a Deus, achara-se. Pajem (p. 44).
\end{abstract}

Há nessa passagem uma subversão na construção normativa dos períodos, pois a pontuação quebra a sua estrutura sintática, o que pode representar um domínio precário da linguagem de Marlindo, como também registrar as rápidas mudanças em sua trajetória. Entre Cataguases e cidades adjacentes, o narrador revela essa personalidade instável de Marlindo, ilustrada também pela fluidez do signo mar presente na partícula inicial de seu nome: MAR/LINDO, o que soa irônico tendo em vista a trajetória da personagem.

As primeiras atividades da personagem estão relacionadas à economia rural ("roça de arroz", "rachando lenha”) e, portanto, são caracterizadas por uma rotina mais flexível, mas não menos intensa. Em seguida, com a decisão de se estabelecer em Cataguases, é representado o desenvolvimento da cidade, que tornou-se um pólo industrial e proporcionou a formação de uma classe operária na região, pois Marlindo, de carteira assinada, começa a trabalhar na fábrica.

Percebendo uma inadaptação ao ser subordinado pelo sistema fabril, buscou atividades autônomas: pipoqueiro e sócio de uma venda, que também não deram certo. Nesse 
momento, é que Marlindo reconhece o papel fundamental da esposa Zulmira, lavadeira de roupas analfabeta, já que ele não era capaz de determinar seu futuro sozinho. $\mathrm{O}$ fato de que Marlindo se fixou como pajem de Osvaldo, que, aos dezessete anos, doente dos nervos, percebeu a inutilidade de sua vida, se deve à postura de Zulmira, que deu um fim a esta situação: "Agora apagara o facho. Assentara praça. Graças à Zulmira, verdade seja dita. Tinha que reconhecer. Por ele, estaria vagando ainda, sem pouso, nem repouso. Ela bateu o pé. Manhou. Não ia mais ficar rolando morro abaixo" (p.44).

Como pajem, sua função era basicamente medicar o menino nas horas certas com injeções calmantes. E, a partir de então, tornou-se um "outro homem" (p.45): se converteu para a Igreja Quadrangular, e, consequentemente, largou cigarro, bebida e pensamentos ruins, também não agrediu mais os filhos. A ética protestante pode ser observada no fato de que mesmo não se adaptando ao sistema de incitação e coerção da indústria capitalista, Marlindo, após converter-se, passou a ter consciência de que era importante almejar uma colocação para ascender socialmente e garantir uma identidade, mas ainda com um pensamento machista, ao reproduzir um discurso que reitera a naturalização da violência contra a mulher, enraizada na sociedade, pois, para a filha, desejava apenas um bom marido que não a violentasse:

Hélia, menina-moça, habitava o mundo da lua. À espera de um príncipe encantado. Que nunca apareceria. Porque não existem. Mas, vá meter isso na cabeçadura dela! Tentara arrastá-la, Deus era testemunha. Conseguia era o deboche. A esculhambação. Namoradeira, fazia vista grossa aos deslizes. Orava por ela. Para que arrumasse logo um marido. Um homem bom. Que não batesse nela (p.45).

E, para o filho Luzimar, sonhava com uma colocação na capital paulista:

Já o menino, o preocupava. Sonhava, com o aval de Deus, um mundo melhor para ele. Um curso de toneiromecânico no Senai. Ou de ajustador mesmo, já estava bom. Morando em São Paulo. Endinheirado. Sem precisar de passar necessidade. Dando de presente para a mãe uma geladeira. Ou uma enceradeira. Orgulho da família. Bem-falado (p. 45).

Nessa passagem, é possível refletir sobre a transformação de perspectiva de Marlindo pois, com a chegada do progresso, mesmo que precário, na cidade de Cataguases, o narrador focaliza pequenas mudanças na trajetória - também precária - de um homem pobre que vivenciou inúmeras incertezas, frustrações e privações, e portanto passou a desejar para o filho um futuro diferenciado. Além de um curso técnico no Senai, Marlindo almejava a mudança de Luzimar para a capital paulista, o que revela uma consciência de que, mesmo com o crescimento da pequena Cataguases, as oportunidades ainda eram limitadas. Enquanto São Paulo recrutava, principalmente de zonas rurais, a partir do período do Estado Novo, a mão de obra então necessária para a indústria.

O salário como objetivo primordial do trabalho também é destacado pela perspectiva de Marlindo que desejava um filho assalariado e com boas condições financeiras, mesmo que distante da família, capaz de presenteá-los com bens materiais de consumo e garantir status na vizinhança. Porém, sabia do empenho e investimento necessários para tais conquistas e reflete: "Mas, para isso, precisava de firmeza. Determinação. Meu Deus, quantos sacos de serragem?, quantos carrinhos-demão cheios de toquinhos teria de empurrar ainda para a mulher ferver roupa para fora? Quantos? (p.45).

Dessa forma, Luiz Ruffato, ao ambientar seu romance em Cataguases, destaca a transição da economia agrária pela industrial que proporcionou o surgimento de uma nova classe de trabalhadores na cidade, conforme ocorreu já na transição do século XIX para o XX. O discurso do progresso, cujas promessas trariam, pelo menos na teoria, melhorias em todos os níveis para a população de modo geral, é problematizado pelo escritor por meio da perspectiva precária de suas personagens, que, mesmo desejando uma mudança de vida, com melhores condições de subsistência, se rotulam como incapazes e buscam alternativas também precárias, provisórias... como é possível exemplificar a partir da trajetória do próprio Zé Pinto, mas também na de Marlindo, Hélia, Luzimar, Gildo, Gilmar, Vanin...

Perpassando pelas demais narrativas-capítulos de $O$ mundo inimigo, em linhas gerais, as descrições não vão de encontro com a da família de Dona Geralda. Grande parte das personagens trabalha nas fábricas, reside no Beco do Zé Pinto e compartilha de uma simplicidade ainda maior do que a casa de Dona Marta, que, aliás, divide muro com o Beco. Vale destacar, inclusive, que as casas industriais, citadas algumas vezes no romance, não são habitadas pelas personagens ruffatianas. Mas, ainda assim a indústria da cidade comandava e influenciava diretamente no cotidiano de seus habitantes, em suas relações sociais, como também em suas perspectivas e anseios, conforme comentado.

Ademais, em algumas situações pontuais, as personagens transitam por outros espaços da cidade, como dona Geralda e Bibica, na Matriz de Santa Rita de Cássia, localizada na praça Santa Rita, Osvaldo, no Colégio Cataguases, Jorginho, na Rodoviária, sonhando com o dia de sua mudança, Zunga, na matinê do Cine Edgar, 
Hélia e as amigas, paquerando na Praça Rui Barbosa ou cobiçando as piscinas do Clube do Remo, entre outros... No entanto, o cenário recorrente ainda é o Beco. As fábricas, apesar de serem referenciadas constantemente na narrativa, só aparecem efetivamente como cenário em "A solução".

As duas passagens a seguir de "A solução" exemplificam esse trânsito quando o narrador observa o caminhar de Hélia, filha de Marlindo, pela cidade:

Quase onze horas e Hélia ainda estava em frente à Estação. O suor banhava seu rosto, seus pés, seus sobacos, colava sua roupa à pele pegajosa. Caminha devagar, os amarinhos vazios, os caixeiros à porta, encostados nos cavaletes, carroças estacionadas no outro lado do passeio, o cheiro forte de mijo e de bosta dos cavalos, moscas voejando, raros carros e ônibus circulam pela rua pacientes, bicicletas sonolentas, um casal atrasa-se olhando uma vitrina, o sol carpe o leito do trem, alcança a Rua do Comércio, passos arrastados, surda, muda, cruza com um grupo de meninas vindas do Colégio das Irmãs (...) (p.69).

No meio da Ponte Nova, parou. Debruçou-se na amureta e ficou observando as águas barrentas do Rio Pomba que, lá na frente, quase na curva da Vila Teresa, recebem a soda e a tinta do Rio MeiaPataca. Na margem esquerda, o fundo dos quintais das casas da Rua do Pomba, imundos de pé-degalinha, marmelada-de-cachorro, capim-gordura, assa-peixe, vassoura, capim-angola, que rastejam por entre mangueiras, abacateiros, ingazeiros, abieiros, goiabeiras, amoreiras, pés-de-carambola. Na margem direita, mato, mato, mato. A Casa de Saúde. Ao fundo, a Pedreira, CASAS PERNAMBUCANAS no alto pichado. As águas barrentas. Dois barcos cheios de areia. E as águas barrentas. Se olhasse para trás, não tinha coragem, veria moças e rapazes queimando nas piscinas do Clube do Remo (p. 72).

A primeira passagem exemplifica uma manhã de verão extremamente quente, típica da região. Outra questão é o destaque dado à bicicleta como meio de transporte, que reaparece em diversos momentos da narrativa. Entretanto, tal meio de transporte só é adquirido por aqueles que trabalham como operários na fábrica, com exceção de Zunga, que percorria de bicicleta a cidade e buscava atividades remuneradas ilegais. Já a segunda passagem destaca a discrepância entre as duas margens do Rio Pomba, como também os efeitos negativos da industrialização que afetaram o meio ambiente. Em outro momento, Zunga, filho de Bibica, também observa tais questões: "Todo mundo sabe que o Rio Pomba é só isso: bosta, mijo e tinta. Nem os peixes aguentaram, seu Marlindo, nem os peixes!” (p. 114).

Referências à linha férrea, tão importante para o desenvolvimento econômico e cultural da cidade, também aparecem no romance em forma de crítica à exportação de bauxita que ocorre na região, nas reflexões de Amaro em "Vertigem":

Da janela do quarto via a estação ferroviária desativada, carroças de aluguel cheiro de mijo de cavalo o trem cortando a cidade como uma cobra minério-de-ferro escapando dos vagões Lá vai a riqueza do Brasil pro estrangeiro uma vergon carros ziguezagueiam buzinas, camelos apregoam contrabandos, caixeiros chamam os passantes (p. 190, grifos do autor).

Nos livros de história que apresentam Cataguases, além dos processos de urbanização e industrialização que ocorreram na cidade de Cataguases, as manifestações modernistas também obtêm grande destaque. No entanto, o modernismo de Cataguases não é focalizado no romance. Apesar de algumas referências a lugares cujo modernismo está presente, não há nenhum momento em $O$ mundo inimigo em que as personagens usufruem deles. É como se ali não houvesse nada particular, revelando, dessa forma, que as artes não fazem parte do cotidiano popular, como também de que há uma conformação da experiência urbana pelo imaginário da população que naturaliza tais monumentos. Ressalva para o cinema, que é frequentado diversas vezes pelas personagens de Ruffato, não para fruição, mas para o lazer. A promessa de cidade moderna, que abarcaria a vida diversa, o outro, resultou falência, cujo isolamento e o autocentramento se sobressaem, reforçando, dessa forma as questões da precariedade, solidão e desintegração.

Exceção ocorre apenas com a personagem Osvaldo, filho de Dona Geralda e Romualdo, como pode ser observado na passagem a seguir. No entanto, mesmo com tais oportunidades, ainda aos dezessete anos, sofreu pelo esgotamento. Seu diagnóstico: doença dos nervos.

Osvaldo conheceu o mar, as serras, as igrejas históricas de Ouro Preto e Mariana, a agitação de Belo Horizonte e do Rio de Janeiro, os filmes nos cines Edgard e Machado, domingo à tarde, as meninas do Colégio Cataguases e do Colégio das Irmãs, a piscina do Clube do Remo, as coleções de livros do pai, os discos, mas nada daquilo the interessava (p.48-49).

Dessa forma, a partir da análise da trajetória das personagens de $O$ mundo inimigo, é possível refletir sobre principalmente duas questões. Primeiro, as estratégias narrativas utilizadas por Luiz Ruffato que permitem que as personagens pertencentes à classe trabalhadora falem por si sem a interferência do narrador. Há na narrativa um narrador (ou narradores) onisciente(s) em terceira pessoa que se comporta(m) de diferentes maneiras nas doze narrativas-capítulos para se aproximar de diferen- 
tes subjetividades, alterando, inclusive, a estrutura da narrativa, o que oferece mais sensibilidade ao romance. Ao optar por uma narrativa não linear, sem um narrador organizador dos fatos e dos pensamentos das personagens, Ruffato permite que o trabalhador fale por si e, portanto, é possível que o leitor aproxime-se um pouco mais das diferentes figurações de sujeitos trabalhadores. Por isso, é que Ruffato é uma exceção na literatura brasileira contemporânea, em relação ao corpus estudado por Dalcastagnè (2012), já que, a partir de seu lugar de fala, representa a classe trabalhadora com seus anseios, sonhos e dificuldades. Segundo, a representação do mundo do trabalho, que tem estado ausente de boa parte da narrativa brasileira contemporânea. Pode-se dizer até que o trabalho tem sido um assunto silenciado e o trabalhador ignorado na atual ficção brasileira. Em $O$ mundo inimigo, essa categoria, sob a perspectiva da racionalidade econômica e a partir do desenvolvimento da cidade de Cataguases, é tratada como fundamental para o cotidiano de suas personagens. Porém, as mudanças trazidas pelo progresso não ofereceram uma mudança significativa na qualidade de vida de todos. O trabalho, portanto, tem um valor na vida do homem moderno, mas ao mesmo tempo esse valor é esvaziado de sentido.

Além disso, as personagens que transitam pelas narrativas de $O$ mundo inimigo, assim como pela cidade de Cataguases, são impedidos a todo instante de (con) viver bem em sociedade e consigo mesmo na dinâmica urbana. O que permite ampliar a discussão sobre os efeitos do processo de desenvolvimento ocorrido no Brasil, que alimentava o desejo da população em ascender socialmente para adquirir bens de consumo, a partir dos processos de monetarização e normatização capitalistas em que o produto industrializado torna-se o que dá importância ao sujeito; e não o fazer parte da sociedade.

\section{Referências}

ASSIS, Machado de (1873). Notícia da atual literatura brasileira. Instinto de nacionalidade. Obra Completa de Machado de Assis, v. III. Rio de Janeiro: Nova Aguilar, 1994. Disponível em: <https://goo.gl/fAsXaK>. Acesso em: 29 out. 2016.
BENJAMIN, Walter (1936). Sobre o conceito da História. In: Magia e técnica, arte e política: ensaios sobre literatura e história da cultura. Obras escolhidas, v. 1. Tradução Sergio Paulo Rouanet. 7. ed. São Paulo: Brasiliense, 1994.

COSTA, Levy Simões da. Cataguases centenária: dados para sua história. Juiz de Fora: Esdeva, 1977.

DALCASTAGNÈ, Regina. Literatura brasileira contemporânea: um território contestado. Vinhedo: Horizonte, 2012.

GIL, Fernando Cerisara. O romance da urbanização. Porto Alegre: EDIPUCRS, 1999.

GOMES, Renato Cordeiro. A cidade, a literatura e os estudos culturais: do tema ao problema. Ipotesi: revista de estudos literários, Juiz de Fora, v. 3, n. 2, p. 19-30, 1999. Disponível em: <https://goo.gl/Cej0NE>. Acesso em: 16 out. 2015.

(1994). Todas as cidades, a cidade: literatura e experiência urbana. 2. ed. Rio de Janeiro: Rocco, 2008.

GONSALES, Célia Helena Castro. Cidade moderna sobre cidade tradicional: conflitos e potencialidades (partes 1 e 2). Arquitextos, ano 05, abr. 2005. Disponível em: <https://goo.gl/ mtm8Wu>. Acesso em: 25 out. 2015.

OLIVEIRA, Marcos Ferreira de. Tecido em ruínas: fabricação e corrosão das Cataguases no Inferno Provisório de Luiz Ruffato. São Paulo: Intermeios; Cataguases: Prefeitura Municipal de Cultura e Turismo, 2013.

RESENDE, Enrique de. Pequena história sentimental de Cataguases. Belo Horizonte: Itatiaia, 1969.

RIO, João do (1910). A alma encantadora das ruas. São Paulo. Martin Claret, 2015.

RUFFATO, Luiz. O mundo inimigo. Rio de Janeiro: Record, 2005. (Inferno Provisório, 2).

SANTOS, Luis Alberto Brandão. Textos da cidade. In: VASCONCELOS, Maurício Salles; COELHO, Haydeé Ribeiro (Org.). 1000 rastros rápidos: cultura e milênio. Belo Horizonte: Autêntica, 1999. p. 131-138. Disponível em: <https://goo. gl/1Gl1xn>. Acesso em: 20 jul. 2016.

SILVA, Arthur Vieira de. O município de Cataguases: esboço histórico. Cataguases: Tipografia da Imprensa Oficial, 1908.

Recebido: 07/03/2017

Aprovado: 18/01/2019

Autoras:

CAMila Galvão de Sousa

camigalvaos@gmail.com

JoELMA SANTANA SIQUEIRA

jandraus@ufv.br 